Edukids volume 15 (1) tahun 2018

EDUKIDS: Jurnal Pertumbuhan, Perkembangan, dan Pendidikan Anak Usia Dini

Jln. Dr. Setiabudhi No. 229 Kota Bandung 40154. e-mail: edukid@upi.edu website: http://ejournal.upi.edu/index.php/edukid

\title{
PENGGUNAAN METODE CERDAS BERBHASA INDONESIA FONIK (CBIFONIK) UNTUK MELATIH KEMAMPUAN MEMBACA PERMULAAN ANAK
}

\section{Oleh :}

\section{Ulfah Salamah, Mubiar Agustin dan Nur Faizah R. ${ }^{2}$}

\author{
Program Studi Pendidikan Guru Pendiddikan Anak Usia Dini \\ Departemen Pedagogik \\ Fakultas Ilmu Pendidikan \\ Universitas Pendidikan Indonesia \\ e-mail:
}

Abstrak: Penelitian ini dilatarbelakangi adanya opini bahwa anak-anak mengalami kesulitan dalam pembelajaran membaca dan menulis sehingga anak kurang memberikan minat yang baik dalam pelajaran membaca. Penguasaan dan pemahaman anak dalam tahapan membaca permulaan masih abstrak, anak masih cenderung menghafal huruf atau bacaan bukan paham dalam membaca. Penguasaan guru dalam pemahaman pembelajaran membaca dan menulis cukup baik. Peran guru dalam proses pembelajaran cukup komunikatif dan guru sudah menggunakan metode serta media pembelajaran dengan baik. Permasalahan yang diangkat dalam penelitian ini adalah bagaimana melatih kemampuan membaca permulaan menggunakan metode cerdas berbahasa indonesia fonik di taman kanak-kanak.Penelitian ini bertujuan untuk mengetahui perencanaan, pelaksanaan dan evaluasi dalam penggunaan metode cerdas berbahasa indonesia fonik (CBIFonik) dalam melatih kemampuan membaca permulaan di Taman Kanak-kanak. Metode yang digunakan dalam penelitian ini adalah Studi Kasus dengan pendekatan kualitatif. Subjek dalam penelitian ini adalah kepala sekolah, dan wali kelas kelompok B. Data penelitian diperoleh melalui wawancara, observasi dan studi dokumentasi. Hasil penelitian menunjukan bahwa: (1) perencanaan untuk menggunakan CBIFonik di TK cukup baik dan tersusun; (2) penerapan metode Cerdas Berbahasa Indonesia Fonik (CBIFonik) dapat dilakukan dengan cara yangbervariasi dan menyenangkan sehingga membantu meningkatkan kemampuan membaca permulaan di taman kanak-kanak; (3) alat dan cara evaluasi penerapan kemampuan membaca permulaan di TK sudah tepat.Penggunaan metode cerdas berbahasa indonesia fonik diterapkan melalui aktitas rutin atau kegiatan sehari-hari, setiap hari seninjumat. Sarana dan prasarana, media atau sumber belajar yang ada sudah dapat menunjang terlaksananya penerapan metode cerdas berbahasa indonesia fonik (CBIFonik) di TKIT An Nahdhoh.

\section{Kata kunci: membaca permulaan, metode cerdas berbahasa indonesia fonik}

Abstract: This research is motivated by the opinion that children experience difficulties in learning to read and write so that children do not give good interest 
in reading lessons. Mastery and understanding of children in the stages of beginning reading is still abstract, children still tend to memorize letters or reading does not understand in reading. Teacher mastery in understanding reading and writing learning is quite good. The role of the teacher in the learning process is quite communicative and the teacher has used methods and learning media well. The problem raised in this study is how to practice the ability to begin reading using an intelligent Indonesian language method of phonics in kindergartens. This study aims to find out the planning, implementation and evaluation in the use of smart Indonesian phonics (CBIFonik) methods in training early reading skills in kindergarten. The method used in this study is a Case Study with a qualitative approach. Subjects in this study were school principals, and group B class guardians. Research data were obtained through interviews, observation and documentation studies. The results showed that: (1) planning to use CBIFonik in kindergarten was quite good and structured; (2) the application of the Phonetic Smart Language (CBIFonik) method can be done in a variety and fun way so as to help improve the early reading skills in kindergarten; (3) the tools and methods for evaluating the application of preliminary reading skills in TK are appropriate. The use of smart Indonesian phonics methods is applied through routine activities or daily activities, every Monday-Friday. Facilities and infrastructure, existing media or learning resources can support the implementation of the Indonesian phonics (CBIFonik) smart method in TKIT An Nahdhoh.

\section{Keyword: reading beginning, phonetic smart language method}

\section{PENDAHULUAN}

Anak usia dini merupakan masa keemasan (golden age), oleh karena itu pendidikan pada masa ini merupakan pendidikan yang sangat fundamental dan sangat menentukan perkembangan anak selanjutnya, (Hartati, 2005). Pada periode ini hampir seluruh potensi anak mengalami masa peka untuk tumbuh kembang dan berkembang secara cepat. Pada masa ini anak sangat membutuhkan stimulasi dan rangsnagan dari lingkungannya. Apabila anak mendapatkan stimulasi yang baik, maka seluruh aspek perkembangan anak akan berkembang secara optimal. (Hartati, 2005)

Menurut Hartati (2005) pembelajaran pada masa golden age merupakan wahana untuk memfasilitasi pertumbuhan dan perkembangan anak guna mencapai tahapan sesuai dengan tugas perkembangannya. Pendidikan anak usia dini dijadikan sebagai kunci utama untuk dapat menghasilkan generasi penerus bangsa yang memiliki wawasan, keterampilan dan kepribadian yang baik. Pendidikan anak usia dini dianggap penting karena di dalam pendidikan ini menitikberatkan pada pertumbuhan dan perkembangan anak yang akan dikembangkan secara optimal, baik perkembangan fisik (motorik kasar dan halus), sosial emosional, bahasa, kognitif dan moral agama.

Salah satu prinsip perkembangan menyatakan bahwa perkembangan merupakan hasil proses kematangan dan belajar. Proses kematangan adalah terbukanya karakteristik yang secara potensial ada pada individu dan berasal dari warisan genetik (Hurlock, 1991). Beberapa proses belajar berasal darilatihan atau pengulangan suatu tindakan yang nantinya menimbulkan perubahandalam perilaku (Hurlock, 1991). Kematangan menentukan siap atautidaknya seseorang untuk belajar, karena betapapun banyaknya rangsangan yangditerima anak, mereka tidak dapat 
belajar dan menghasilkan perubahan perilakusampai mereka dinyatakan siap menurut taraf perkembangannya.

$$
\text { Havighurst (Hurlock, }
$$

menamakan kondisi kesiapan belajar yang ditentukan olehkematangan ini sebagai teachable moment, atau saat yang tepat bagi anak untuk"diajar".

Menurut Montessori

(dalam

Hainstock, 2002), masa peka anak untuk belajar membaca dan berhitung berada di usia 4 - 5 tahun, karena di usia ini anak lebih mudah membaca dan mengerti angka. Doman (2005) menyarankan sebaiknya anak mulai belajar membaca di periode usia 1 hingga 5 tahun. Menurutnya, pada masa ini otak anak bagaikan pintu yang terbuka untuk semua informasi, dan anak bisa belajar membaca dengan mudah dan alamiah. Namun menurut Dardjowidjojo (2003), dari segi neurologis pada usia 1 tahun otak 27 baru berkembang $60 \%$ dari otak orang dewasa. Di usia ini anak belum dapat mengidentifikasi letak garis lurus dan setengah lingkaran apalagi kombinasinya,maka anak belum mungkin belajar membaca.

Sementara menurut $\begin{aligned} & \text { Grainger } \\ & \text { memulai }\end{aligned}$
pengajaran
membaca tergantung pada fonemis. Istilah ini meliputi banyak aspek kepekaan anak terhadap struktur bunyi kata lisan, menentukan kemampuan memetakan bunyi ke simbol yang penting untuk membaca, menulis, dan mengeja.

Fonem merupakan bunyi terkecil dari sebuah huruf. Maka, metode pengajarannya setiap huruf dalam kata yang disebutkan lebih ditekankan. Dalam metode CBIFonik, anak akan mengetahui bentuk dan bunyi huruf dan anak dapat mengasosiasikan suatu rangkaian bunyi. Kedua kecakapan ini harus dikuasai anak agar belajar membaca dapat berjalan dengan lancar. Pengajaran membaca tidak perlu diajarkan secara tergesa-gesa. Membaca dan menulis diajarkan secara bersama dalam metode CBIFonik sehingga anak terbiasa mengeja apa yang dibaca dan apa yang ditulis. Dengan demikian, kecenderungan anak untuk membaca secara hafalan sangat kecil. Kemampuan berbahasa tidak selalu ditunjukkan oleh kemampuan membaca saja, tetapi juga kemampuan lain seperti penguasaan kosa kata, pemahaman dan kemampuan berkomunikasi.

Metode CBIFonik merupakan suatu metode yangberhubungan dengan suara dan tulisan. Kemungkinannya mengubah suara ke dalam tulisan.Metode fonik adalah cara belajar membaca yang didasarkan pada bunyi fonologi tiap-tiap bahasa sehingga masing-masing bahasa memiliki kaidah fonologi (unit suara) yang berbeda.

Metode CBIFonik menstimulasi kemampuan literasi yang dirancang dari kemampuan yang paling dasar yaitu memahami bunyi yang bermakna. Peningkatan kemampuan membaca anak melalui metode fonik merupakan kegiatan yang menyenangkan dan memudahkan bagi anka untuk membaca melalui beberapa tahapan, (Thahir, 2007)

Fonem merupakan bunyi terkecil dari sebuah huruf. Maka, metode pengajarannya setiap huruf dalam kata yang disebutkan lebih ditekankan. Dalam metode CBIFonik, anak akan mengetahui bentuk dan bunyi huruf dan anak dapat mengasosiasikan suatu rangkaian bunyi. Kedua kecakapan ini harus dikuasai anak agar belajar membaca dapat berjalan dengan lancar. Pengajaran membaca tidak perlu diajarkan secara tergesa-gesa. Membaca dan menulis diajarkan secara bersama dalam metode CBIFonik sehingga anak terbiasa mengeja apa yang dibaca dan apa yang ditulis. Dengan demikian, kecenderungan anak untuk membaca secara hafalan sangat kecil. Kemampuan berbahasa tidak selalu ditunjukkan oleh kemampuan membaca saja, tetapi juga kemampuan lain seperti 
penguasaan kosa kata, pemahaman dan kemampuan berkomunikasi.

Metode CBIFonik merupakan suatu metode yangberhubungan dengan suara dan tulisan. Kemungkinannya mengubah suara ke dalam tulisan.Metode fonik adalah cara belajar membaca yang didasarkan pada bunyi fonologi tiap-tiap bahasa sehingga masing-masing bahasa memiliki kaidah fonologi (unit suara) yang berbeda.

Metode CBIFonik menstimulasi kemampuan literasi yang dirancang dari kemampuan yang paling dasar yaitu memahami bunyi yang bermakna. Peningkatan kemampuan membaca anak melalui metode fonik merupakan kegiatan yang menyenangkan dan memudahkan bagi anka untuk membaca melalui beberapa tahapan, (Thahir, 2007)

TKIT An Nahdhoh Purwakarta adalah salah satu sekolah Islamyang ada di Kabupaten Purwakarta. TKIT An Nahdhoh Purwakarta dalam menstimulasi perkembangan bahasa anak khususnya dalam aspek membaca permulaan sudah cukup baik dilihat dari pemilihan metode yang digunakan

Berdasarkan latar belakang yang telah diuraikan, maka penelitian memfokuskan kajian penelitian tentang Penggunaan Metode Cerdas Berbahasa Indonesia Fonik (CBIFonik) untuk Melatih Kemampuan Membaca Permulaan Anak. Adapun rumusan masalah dalam penelitian ini dijabarkan dalam pertanyaan sebagai berikut:

1) Bagaimana

persiapan/perencanaan

pelaksanakan pembelajaran

membaca

permulaan

menggunakan metode

CBIFonik di TKIT An

Nahdhoh?

2) Bagaimana penerapan metode dan media CBIFonik dalam meningkatkan kemampuan membaca permulaan anak di
TKIT An Nahdhoh

Purwakarta?

3) Bagaimana evaluasi penerapan metode CBIFonik dalam meningkatkan kemampuan membaca permulaan anak di TKIT An Nahdhoh Purwakarta?

Sesuai dengan rumusan masalah di atas, maka tujuan penelitian ini adalah sebagai berikut:

1) Untuk mengetahui persiapan/perencanaan yang dilakukan untuk menerapkan metode CBIFonik dalam pembelajaran membaca permulaan di TKIT An Nahdhoh.

2) Untuk mengetahui pelaksanaan metode CBIFonik dalam meningkatkan kemampuan permulaan membaca anak di TKIT An Nahdhoh Purwakarta.

3) Untuk mengetahui peningkatan kemampuan permulaan membaca di TKIT An Nahdhoh Purwakarta dengan metode CBIFonik.

\section{METODE PENELITIAN}

Metode penelitian ini menggunakan metode penelitian studi kasus dengan pendekatan kualitatif. Menurut sugiyono (2015) yaitu suatu bentuk penelitian yang berlandaskan pada sifat postpositivisme, digunakan untuk meneliti pada kondisi objek alamiah dimana peneliti adalah sebagai instrumen kunci. Pengambilan sampel sumber data dilakukan secara purposive. Metode studi kasus dengan pendekatan kualitatif, menurut Stake (dalam Creswell, 2010) mengemukakan bahwa :

"Metode studi kasus merupakan strategi penelitian di mana di dalamnya peneliti menyelidiki secara cermat suatu program, peristiwa, aktivitas, proses, atau sekelompok individu. Kasus- 
kasus dibatasi waktu dan aktivitas, dan peneliti mengumpulkan informasi secara lengkap dengan menggunakan berbagai prosedur pengumpulan data berdasarkan waktu yang telah ditentukan,"

Tujuan utama dalam penelitian ini adalah menggambarkan tentang suatu keadaan secara objektif. Penelitian ini bersifat alamiah, karena objek yang dikembangkan apa adanya, serta kehadiran peneliti pun tidak ada pengaruh pada objek tersebut. Penelitian data yang disajikan dalam bentuk deskriptif bersumber dari data yang telah dikumpulkan berupa hasil observasi, wawancara, dan dokumentasi. Rancangan instrument penelitian dalam pengumpulan data masih bersifat sementara dan akan berkembang setelah peneliti memasuki objek penelitian. Selain itu dalam memandang realitas itu bersifat holistik (menyeluruh), dinamis, tidak dapat di pisah- pisahkan ke dalam variable penelitian (Tias, 2017, hlm 32).

Penelitian ini mengambil partisipan satu kepala sekolah, satu orang guru kelas yang beralamatkan di Perum Griya Abdi Negara rt/rw 23/07 Sukatani Purwakarta

Instrumen yang digunakan dalam penelitian yaitu human instrument. Instrumen dikembangkan dari rumusan masalah dengan menggunakan teknik pengumpulan data melalui observasi, wawancara, dan studi dokumentasi.

Analisis data yang digunakan dalam penelitian data adalah analisis data kualitatif. Hancock \&Algozzine (2006) mengungkapkan bahwa analisis tematik adalah memberikan pelaporan dengan menekankan pada jawaban-jawaban atas pertanyaan penelitian, sehingga mengahsilkan tema-tema pelaporan yang sesuai dengan hasil penelitian.

HASIL PENELITIAN DAN PEMBAHASAN
1. Perencanaan Metode CBIFonik di TKIT An Nahdhoh

Berdasarkan hasil wawancara dengan seluruh partisipan, dapat disimpulkan bahwa perencanaan dalam penggunaan metode CBIFonik di lakukan dengan melibatkan pihak-pihak yaitu kepala TK, Guru Kelas dan Yayasan Pustaka Hati sebagai penyedia Metode CBIFonik.

Perencanaan ketika memilih metode CBIFonik untuk digunakan di TKIT An Nahdhoh Purwakarta karena metode CBIFonik dianggap oleh Kepala Sekolah dan Guru cukup membantu untuk melatih kemampuan membaca permulaan anak dengan penggunaan media yang bervariasi dan menyenangkan.

Suatu pembelajaran yang baik adalah pembelajaran yang disiapkan sebelum pelaksanaan pembelajaran dilakukan. Di TKIT An Nahdhoh setiap awal tahun pembelajaran atau awal semester Kepala Sekolah mengumpulkan semua guru seminggu sebelum tanggal masuk sekolah untuk mempersiapkan membelajaran satu semester. Kepala Sekolah mengarahkan apa saja yang akan diterapkan pada satu semester dalam proses kegiatan pembelajaran termasuk penerapan metode CBIFonik, menyusun RKH, RKM serta RKS, guru-guru dan kepala sekolah pun menyusun kegiatankegiatan yang akan dilakukan selain proses belajar mengajar. Selain itu Guru pun menyiapkan lingkungan pembelajaran di kelas seperti menghias kelas, merapihkan kelas dan membersihkan kelas.

Sebelum masuk sekolah dan tiap bulan orang tua murid wajib membayar uang spp dan cicilan uang pangkal yang sudah termasuk uang seragam dan fasilitas penunjang pembelajaran. Sebagian dari uang pangkal tersebut digunakan oleh pihak sekolah untuk membeli media pembelajaran salah 
satunya adalah media pembelajaran metode CBIFonik. Dana didapatkan dari uang pangkal ketika murid masuk sekolah. Yang nantinya akan dialokasikan pada penyediaan media pembelajaran menggunakan metode CBIFonik.

Guru melakukan persiapan sebelum kegiatan membaca permulaan pada metode CBIFonik memerlukan beberapa media. Media yang digunakan dalam metode CBIFonik adalah lembar Foster Fonem Bahasa Indonesia, Buku Gambar Ukuran $30 \mathrm{~cm}$ (Pilihan), Kartu dan Label Fonik, Huruf Timbul (Huruf Raba), Huruf Pisah dan Daftar Kata. Guru menyiapkan media fonik sehari sebelumnya atau satu jam sebelum jam masuk sekolah.

\section{Pelaksanaan Metode CBIFonik di TKIT An Nahdhoh}

Berdasarkan hasil wawancara dan studi dokumentasi serta observasi dengan guru dan kepala sekolah, berkaitan dengan pelaksanaan penggunaan metode CBIFonik untuk melatih kemampuan membaca permulaan anak, sekolah melakukan kegiatan pembelajaran membaca permulaan setiap harinya. Pembelajaran membaca permulaan menggunakan metode CBIFonik dilakukan setiap hari mulai pukul 07.30 08.30 wib di ruang kelas $\mathrm{B}$.

$$
\text { Pembelajaran membaca }
$$

permulaan menggunakan metode CBIFonik dilakukan sebelum baris berbaris dan membaca ikrar. Pukul 07.30 anak sudah berada di dalam kelas untuk kegiatan pembelajaran membaca. Anak diminta untuk membaca ta'awudz dan basmalah kemudian membaca buku UMMI yaitu metode belajar membaca al qura'an yang disebut metode UMMI, kemudian anak menghafal surat pendek hadits dan doa pilihan setelah itu anak belajar membaca menggunakan media fonik. Semua dilakukan satu persatu, setiap anak dipanggil oleh guru, seperti sedang privat belajar membaca. Anak yang lain menunggu giliran diminta untuk belajar menulis di buku yang telah disediakan oleh guru.

Pada kegiatan inti pun guru terkadang melakukan recalling apa yang sudah dipelajari anak di pagi hari dengan permainan fonik. Hal pertama yang dilakukan guru adalah membagi anak ke dalam tiga kelompok, guna memudahkan penilaian terhadap hasil kerja dan aktivitas anak dalam proses pembelajaran. Guru mengawali pembelajaran dengan menyebutkan aturan main yang disepakati dengan anak. Guru memperlihatkan jenis alat peraga CBIFonik yang akan digunakan dalam pembelajaran dan menjelaskan materi pembelajaran yang akan disampaikan.

Ketika pelaksanaan pembelajaran menggunakan metode/medi fonik gur terkadang mengalami kendala dan kesulitan, kendala dan kesulitan yang dialami guru dan murid selama pembelajaran membaca permulaan dilaksanakan adalah anak mudah bosan dengan cara penerepan pembelajaran membaca permulaan yang seperti sedang privat, anak harus menyelasaikan pekerjaan menulisnya sambil menunggu giliran dipanggil oleh ibu guru sehingga ada beberapa anak yang sulit untuk diminta mengikuti kegiatan membaca permulaan menggunakan metode CBIFonik.

Cara yang dilakukan guru untuk mengatasi kendala atau kesulitan selama permbelajaran membaca permulaan berlangsung. Guru membujuk anak untuk tetap mengikuti pembelajaran membaca permulaan dengan mencari cara yang lebih menarik dalam menerapkan metode CBIFonik pada anak. Seperti mengadakan permainan huruf dan tebak kata, guru juga menyanyikan lagu fonik.

\section{Evaluasi Metode CBIFonik di TKIT An Nahdhoh}


Berdasarkan hasil wawancara dan studi dokumentasi, dalam evaluasi penggunaann metode CBIFonik duntuk melatih kemampuan membaca permulaan anak di TKIT An Nahdhoh, alat evaluasi yang digunakan yaitu lembar penilaian yaitu observasi menggunakan media fonik seperti kartu fonik, huruf raba, lagu fonik yang ada di CD dan buku baca tahap 1 dan 2. Kemampuan membaca anak juga ditulis di Buku Prestasi dengan tujuan orang tua mengetahui sudah sampai mana kemampuan membaca anaknya dan harapannya di rumah orang tua pun melatih anak membaca di rumahnya ketika malam hari atau ketika waktunya anak belajar di rumah sesuai dengan waktu yang ditentukan oleh orang tua. Sedangkan buku BACALAH adalah buku belajar membaca yang diberikan oleh sekolah untuk anak sesuai dengan kemampuan setiap anak. Buku BACALAH terdiri dari buku bacalah 1A, 1B, I, II dan III semua tingkat kesulitan disesuaikan setiap seri bukunya. Buku BACALAH digunakan untuk melatih anak membaca di rumah.

\section{SIMPULAN}

\section{A. IMPLIKASI}

Adapun implikasi dari penelitian ini diantaranya yaitu sebagai berikut:

1. Bagi Peneliti

Bagi Peneliti, temuan penelitian ini dapat memberikan gambaran mengenai Metode Cerdas Berbahasa Indonesia Fonik.

2. Bagi Lembaga/Sekolah

Bagi lembaga/sekolah, temuan penelitian ini dapat memberikan implikasi dalam Penggunaan metode CBIFonik di Taman Kanak-kanak.

\section{B. REKOMENDASI}

Berdasarkan simpulan hasil penelitian di atas, rekomendasi yang disampaikan sebagai berikut :
1) Kepala Sekolah dan Guru TK

Guru diharapkan memanfaatkan hasil penelitian ini untuk mengembangkan strategi pembelajaran kemampuan membaca permulaan anak usia dini dan mencobanya dalam meningkatkan kualitas kemampuan membaca anak usia dini melalui hasil penelitian pengunaan metode CBIFonik agar dapat diterapkan dengan baik maka guru perlu mengupayakan hal-hal sebagai berikut:

a) Lebih memfariasikan berbagai teknik pembelajaran agar anak tidak cepat bosan.

b) Lebih mengintegrasikan pembelajaran dalam setiap kegiatan.

c) Mampu mengelola kelas dan menciptakan pembelajaran yang menyenangkan.

d) Guru harus menjadi pembimbing, memandang anak dengan bijak, menghargai potensi anak dan menjadi fasilitator dalam proses pembelajaran anak.

e) Guru membuka wawasan dengan mengikuti pelatihan-pelatihan atau seminar tentang model-model pembelajaran yang lebih beragam.

f) Mendorong motivasi anak untuk senantiasa belajar dengan nyaman dan menyenangkan baik di sekolah maupun di rumah.

2) Lembaga Pendidikan Anak Usia Dini Sejenis

Lembaga Pendidikan Anak Usia Dini Sejenis diharapkan melihat langsung kondisi di lapangan (TK) dan bisa memfasilitasi hal berikut:

a. Merumuskan materi pembelajaran yang bisa meningkatkan kualitas pembelajaran di TK.

b. Mengadakan pelatihan bagi calon guru untuk meningkatkan kualitas pembelajaran dan profesionalisme guru terutama dalam pemilihan materi, metode dan media pembelajaran serta pengelolaan kelas yang kondusif. 
c. Mengembangkan model-model pembelajaran baru yang menyenangkan bagi anak sehingga tujuan pembelajaran di TK yaitu belajar sambil bermain dan bermain sambil belajar bisa tercapai.

d. Menyiapkan calon-calon guru yang dibekali dengan keilmuan yang sesuai dengan kurikulum TK.

e. Mensosialisasikan metode CBIFonik untuk pembelajaran bahasa Indonesia di TK secara menyeluruh.

4) Bagi Orang Tua

Diharapkan dapat meningkatkan kerja sama dengan pihak sekolah berkaitan dengan penerapan metode cerdas berbahasa indonesia fonik (CBIFonik) untuk anak usia dini agar pendidikan yang di tanamkan oleh guru di sekolah dapat sejalan dengan pendidikan yang orang tua tanamkan di rumah.

5) Peneliti selanjutnya.

Keterbatasan peneliti dalam menuangkan hasil penelitian ini tidak lepas dari keterbatasan kemampuan peneliti dalam mengelola kegiatan penelitian, oleh karena itu kepada peneliti selanjutnya direkomendasikan hal berikut :

a. Melakukan penelitian secara lebih rinci dan mendalam terhadap penggunaan atau penerapan metode CBIFonik dalam meningkatkan kemampuan membaca permulaan anak usia dini.

b. Identifikasi media lain yang dapat digunakan sebagai media penyampai materi pembelajaran membaca permulaan anak usia dini.

\section{DAFTAR PUSTAKA}

Creswell, J. W. (2010). Research design: Pendakatan kualitatif, kuantitatif, dan mixed. Yogyakarta: PT Pustaka Pelajar.

Dardjowidjojo, S. (2003). PsikoLinguistik Pengantar Pemahaman Bahasa. Jakarta: Yayasan Obor Indonesia.

Doman, G. \& Doman, J. (2005). How to Teach Your Baby to Read: Bagaimana Mengajar Bayi Anda Membaca (Alih Bahasa: Grace Satyadi). Jakarta: Tigaraksa Satria.

Elizabeth, G. Haincock. (2002). Montessory Untuk Sekolah Dasar. Jakarta: Delaprarasa Publishing.

Grainger, J. (2003). Problem Perilaku, Perhatian, dan Membaca pada Anak:

Strategi Intervensi Berbasis

Sekolah (Alih Bahasa: Enny Irawati). Jakarta: Grasindo.

Hartati, Sovia. (2005). Perkembangan Belajar Pada Anak Usia Dini. Jakarta : Departemen Pendidikan Nasional.

Hurlock, E. B. (1991). Perkembangan Anak Jilid 1 (Alih Bahasa Meitasari Tjandrasa dan Muslichach Zarkasih). Jakarta : Erlangga.

M. Thahir, Sumarti. (2007). Modul Pelatihan CBIFonikPanduan MateriPengembangan Bahasa Indonesia AnakUsia Dini Tingkat Dasar.Depok : Pustaka Hati Educenter.

Sugiyono. (2015). Metode Penelitian Kombinasi (Mix Methods). Bandung: Alfabeta. 